\title{
A theoretical model of transformational leadership and organizational identification of employees : The role of organizational learning, organizational justice and psychological empowerment
}

\author{
Suchandra Bose ${ }^{1}$, Dr.Bhaswati Patnaik ${ }^{2}$ \\ ${ }^{1}$ Research Scholar, Department of Humanities \& Social Sciences.National Institute of Technology(NIT), Rourkela. \\ Rourkela-769008, India
}

suchandra127@gmail.com

${ }^{2}$ Associate Professor, Department of Humanities \& Social Sciences,National Institute of

Technology(NIT),Rourkela. Rourkela-769008 India

bhaswati.patnaik@gmail.com

\begin{abstract}
Transformational leaders inspire and motivate their followers to achieve extraordinary outcomes and in the process, improve their own leadership capacity. Transformational leadership is known to have a positive effect on followers' work outcomes such as productivity, commitment, job satisfaction and so on. The attrition rate in organisations reduces with the increase in employee's loyalty, job satisfaction and commitment to their work. The more the employees identify with the organisation, the more they are likely to continue their jobs for a longer period of time. It is imperative to know, from the management point of view, as to what contributes to the employee identification with the organisation, so that sustainability in productivity can be achieved. The rationale of the proposed study is to understand the underlying organizational mechanisms through which transformational leadership determine employees' organizational identification. Different transformational leader behaviours involve different influence processes. Research evidences show that Transformational Leadership influences both organizational learning and organizational justice. The constructs of organizational learning and organisational justice are important in determining work related attitudes and emotions respectively. The objective of the present study is to develop a theoretical model to examine how the constructs of transformational leadership, organizational learning, and organizational justice relate to the employees' psychological empowerment and organisational identification of the employees. The article is concluded with a discussion on the implications of the model and the possible limitations in the model.
\end{abstract}

\section{Indexing terms/Keywords}

transformational leadership, organizational learning, organizational justice, psychological empowerment, organizational identification.

\section{Academic Discipline And Sub-Disciplines}

Business Management;

\section{SUBJECT CLASSIFICATION}

Management Classification

\section{TYPE (METHOD/APPROACH)}

Theoretical Approach

\section{Council for Innovative Research}

Peer Review Research Publishing System

Journal: International Journal Of Management \& Information Technology

Vol. 10, No 5

editorsijmit@gmail.com

www.jjmit.com 


\section{INTRODUCTION}

Today's businesses realize that maintaining and developing the continuous potential of its workforce is the key to remain competitive in the environment. The key success factor of any organization is its employees. The organization is fully dependent on its employees for its growth and development. Development of businesses itself is determined by both external and internal factors. While external factors relate to global and national trends of the business, the internal factors relate to leadership. Companies need to invest in leadership development, as it is an important aspect that could catalyze business growth in turbulent times. Coping with this turbulence is the key to competitive success. Since leaders are at the helm of affairs in organizations, only they can successfully pilot organizations and teams by maneuvering adroitly through the shoals of change (Brown \& Eisenhardt, 1997). The leader must work at getting large numbers of people in the organization involved in the transformation process, failing which may result in cynicism and strong resistance, and hence bound to frustrate all attempts at change (Kanungo and Misra, 2004).

The role of leadership in any organization cannot be overempasized. Leadership was initially seen as an exchange process (Homans , 1950 ). However, it was James Mcgregor Burns (1978) who conceptualized leadership into its two present forms: transformational leadership and transactional leadership. Transformational leaders are those who inspire and motivate their followers to achieve extraordinary outcomes and also in the process improve their own leadership capacity. Transactional leaders are those who believe in exchange relationship. When subordinates perform well they are rewarded and when they perform poorly they are punished.

Since the past two decades, transformational leadership has emerged as one of the most researched theories in the organizational behavior domain in the understanding of leadership effectiveness.(Piccolo and Colquitt, 2006; Barling, Christie and Turner, 2008). Research evidences suggest that transformational leadership has a positive effect on follower work attitudes and performance at both the individual as well as at organizational levels (e.g., Lowe, Kroeck, \& Sivasubramaniam, 1996). Meta analytic reviews have shown positive associations between transformational leadership and work outcomes of interest to the organisation such as job satisfaction, organizational commitment etc. (Judge \& Piccolo, 2004; Lowe et al., 1996). In spite of this, limited attention has been paid to the organisational mechanisms underlying these relationships (Avolio et al., 2004). Some leadership researchers (e.g., Shamir, House, \& Arthur, 1993; Yukl, 2010) however consistently emphasize that different transformational leader behaviours might involve different influence processes.

This article explains a model of how transformational leadership affects the organizational identification of employees through the processes of organizational learning, organizational justice and psychological empowerment and thus gives a clear understanding of how capabilities and performance of employees can be strengthened to meet organizational excellence.

\section{LITERATURE REVIEW}

Leadership management in the organisation is moving towards the trend of Transformational Leadership (Crawford, 2005). Transformational Leadership can be defined as the way of leadership that aims performance beyond the subordinate's expectations by transforming their emotions, thoughts, beliefs and values. (Rafferty \& Griffin, 2004). It has four components namely idealized influence, inspirational motivation, intellectual stimulation and individualised consideration (Bass, 1985).

According to transformational leadership theory (Bass, 1985) and self-concept-based explanations of such leadership (Shamir et al., 1993; Sosik \& Cameron, 2010), transformational leaders influence followers' self-definitions, affect, values, beliefs, and behaviours.

Research evidences show that transformational leadership is positively related to organizational learning (Bhat, 2013; Garcia, 2012; Hugo, Vlado \& Miha, 2009). Organizational learning is a social phenomenon (Bhat, 2013). An individual's learning depends on the knowledge that other members of the organization possess (Figueiredo, 2003). The social interaction not only facilitates coordination and communication but also learning. In order to leverage knowledge based resources throughout the organization, the firm should promote organizational learning (Tetrick \& Da Silva, 2003). According to S Ganapathy and Kumar (2000), Organizational learning occurs at three levels - at the individual level learning is all about development of one's specific skills at the work place, at the group level members obtain a context for learning and guidance through shared experiences and at the organizational level, learning is more formal and results in the development and maintenance of procedures to enhance learning outcomes.

Research evidences also suggest that transformational leadership positively affects organizational justice (Rokhman \& Hassan , 2012 ; Pillai , Schriesheim, Williams,1999).According to Greenberg (1990) organizational justice refers to the employees perception of fairness in organization including how decisions are made regarding the distribution of outcomes and the perceived fairness of those outcomes. Transformational leaders emphasize organizational justice, so that followers are more likely to identify with the leader and the organization. (Zhu, Sosik, Riggio \& Yang, 2012)

Both these constructs of organizational learning and organisational justice are important in determining work related attitudes and emotions respectively. Thus the employees feel more emotionally attached to and involved in the organization. They feel a sense of ownership and more psychologically empowered. According to K.W Thomas and Velthouse (1990), psychological empowerment is defined as the intrinsic motivation manifested in four cognitions reflecting an individual's orientation to his or her work role. The four dimensions are meaning, competence, selfdetermination and impact. Meaning refers to a fit between one's work role requirement and one's beliefs, values and behaviours. (Brief and Nord, 1990). Competence refers to one's belief in his capability to perform work activities with skill. (Gist and Mitchell, 1992). Self-determination refers to the sense of choice in initiating and regulating one's actions. (Deci 
and Ryan, 1985). Impact is the degree to which one can influence strategic, administrative or operating outcomes at work. (Ashforth, 1989). According to Bass (1985) they also empower followers to recognize the importance of their work and develop their knowledge, skills and abilities to reach their full potential.

Gary Yukl (2010) proposed that leadership enables the process of building commitment to the organization's objectives and can empower followers to accomplish these objectives. Followers who feel more empowered tend to reciprocate by being more committed to their organization (Koberg et al., 1999; Wang \& Lee, 2009), which suggests that followers may be more likely to identify with their organization. Organizational Identification is defined as the organizational member's perception of oneness with the organization (Ashforth \& Mael, 1989). Organizational Identification includes cognitive as well as emotional components (Zhu, Sosik, Riggio, 2012)... The cognitive component refers to the common interests that an individual shares with the organization and the calculative benefits that he/she gains by association with the organisation. The emotional component refers to an individual's positive image of one's organisation.

Transformational leaders are likely to be associated with empowered followers who possess strong identification with their organizations. Transformational leaders empower their followers and pay attention to their individual needs and personal development.

According to Hater and Bass (1988) considerable research has been done on exchange relationship between the leader and subordinate. The concept of transformational leadership is based on strong personal identification and going beyond a self interested exchange of rewards between the leader and the subordinate. The question thus arises is how does this transformational leadership make a difference in the follower's identification. There are studies which have explored the relationship between transformational leadership and employee identification, however the underlying mechanisms have not been entirely clear. The academia is yet to fully examine the mediating factors between transformational leadership and employee identification. Additionally most of the studies have been conducted in the Western Context. There is a need to examine this leadership construct in other cultural contexts. The present study is based on these concerns, and takes into account the constructs of Organizational Learning, Organizational Justice and Psychological Empowerment in establishing the relationship between Transformational Leadership and Employee's Organizational Identification.

\section{THEORETICAL MODEL AND PROPOSITION DEVELOPMENT}

The following figure depicts a model in which it is proposed that the constructs of organizational learning, organizational justice and psychological empowerment links the relationship between transformational leadership and organizational identification of employees. There are ten propositions explaining the theoretical logic of each of the proposed relationships between the variables in the model. The propositions were developed in the following steps: 1 . Independent variable (Transformational leadership) relates to the outcome variable (Organizational Identification). 2. Independent variable (Transformational Leadership) relates to mediators (Organizational Learning, Organizational Justice and Psychological Empowerment). 3. Independent variable (Transformational Leadership) relates to the variable (Psychological Empowerment) through the mediator variables (Organizational Learning, Organizational Justice). 4. The outcome variable (Organizational Identification) relates to the mediator variable (Psychological Empowerment). 5. The independent variable (Transformational Leadership) relates to Outcome Variable (Organizational Identification) through the mediating variable (Psychological Empowerment).

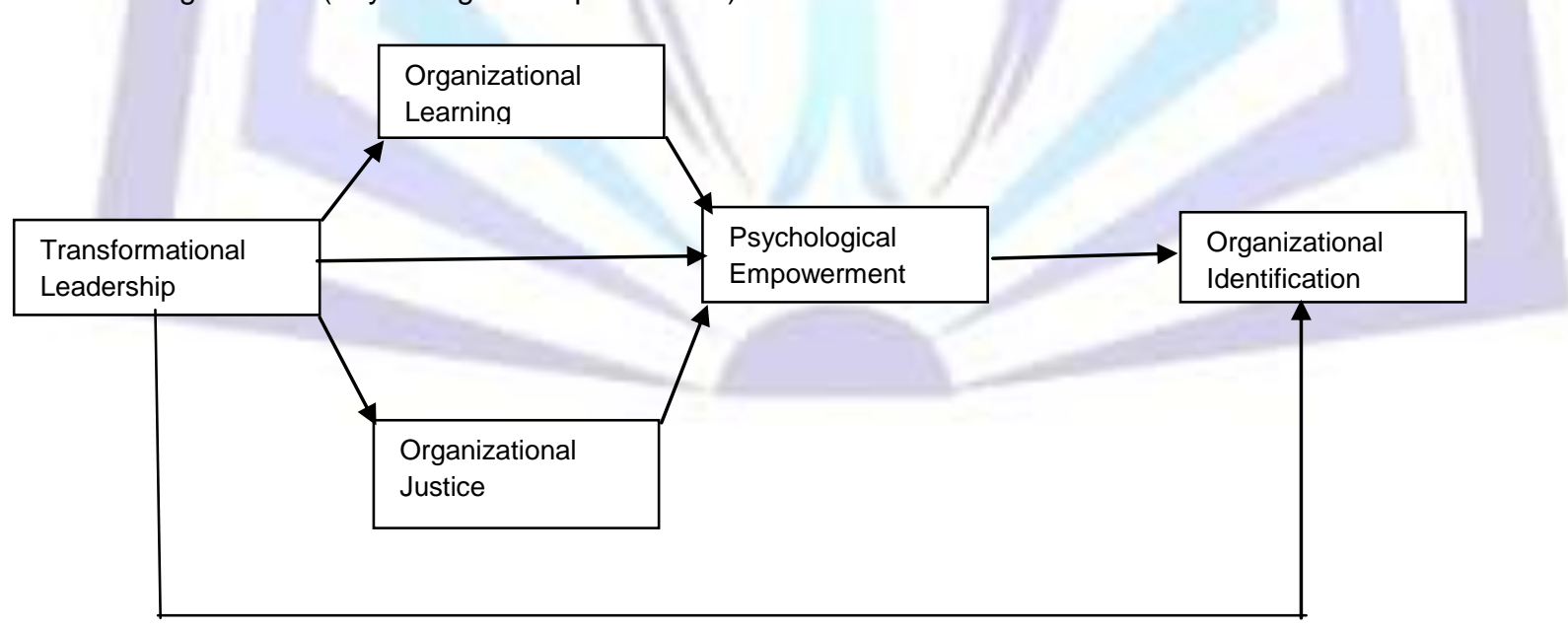

\subsection{Transformational Leadership and Organizational Identification of Employees}

To understand the impact of transformational leadership social identity is an important construct. Tajfel (1978) defined social identity as "that part of an individual's self-concept which derives from his knowledge of his membership of a social group together with the value and emotional significance attached to that membership." According to Foote (1951), people tend to identify with others in the group and thus categorise themselves with the social world around them, such categorizations help form commitment resulting in motivating behaviour. According to Kark and Shamir (2002), transformational leaders influence followers' self-concept in two ways: the relational and the collective self. Followers identify with their particular leader through the relational aspects of the followers' self-concept, while organizational or social identification is influenced by priming of their collective self. Transformational leaders increases followers' contribution to membership or group, and then shift followers' identification from the individual level to the collective level 
(Shamir, Zakay, Breinin and Popper, 1998). Furthermore, leaders can create group level influences, including collective identification, by establishing symbolic activities, which will increase follower self-esteem and consequently lead to organizational identification (Shamir et al., 1993). Transformational leaders help followers to see themselves as being "one" with the organization and as such help the followers to contribute to the collective (Ashforth \& Mael, 1989). Transformational leaders go beyond their self interest in development of their followers. They encourage a supportive work environment to develop the employees' skills, and solve various work challenges. They give constructive suggestions and feedback to the employees and thus resulting in developing a positive feeling for the organization and being a member of the organization which in turn helps in increasing the identification of the employees with the organization. Thus,

Proposition 1: Transformational leadership will have positive and significant impact on organization identification of employees

\subsection{Transformational Leadership and Organizational Learning}

Human capital is the most essential resource in any organization. Thus managers need to harness this capital in the most effective and efficient manner. According to a study by Newberry (2008), human resources are the most vital element in any organization. Leadership is the key tool to bring about any changes in them. Transformational leaders are the leaders who stimulate their employees to do their work with performance beyond expectations. This leadership style has an advantage such as improving the organizational learning in an organization (Mansadi et al, 2014). According to a study ( $\mathrm{K}$ Singh ,2005), the conversion of an organization to a learning organization requires changes in the whole system, and this change cannot take place without the implementation of transformational leadership. This study claimed that it is the intellectual stimulation component of the transformational leadership which brings about creativity and innovation in the employees and thus leads to organizational learning. Study by Kurland (2010) states that transformational leadership can predict organizational learning. A study by Aragon-Correa et al (2005) shows that transformational style of leadership enables the organizational members ability to create and use knowledge in the organizations. Dodgson (1993) opines that an organization need to learn to reform and improve their power and adaptability against the environmental changes. Grantham (1993) in his research also argued that learning organizations are adaptive also effective in competitive environment. Shine (2004) in his research agrees on the integration of these two constructs of transformational leadership and organizational learning and claims that these two variables are necessary strategies of change in any organization. Thus, it can be proposed that transformational leadership has an important role in enabling its employees to learn, to be creative. These are the leaders who try to create an environment of trust and cooperation in the organization and hence create a culture of organizational learning. Thus,

Proposition 2: Transformational Leadership is positively and significantly related to Organizational Learning

\subsection{Transformational Leadership and Organizational Justice}

Organizational Justice is very important in the successful running of any organization. According to Greenberg (1990), organizational justice refers to the employees 'perception of fairness in the organization which also includes the decisions being made, the distribution of the outcomes and the fairness of these outcomes. Organizational justice patterns in the organizations helps in developing a bond of trust amongst the employees and its organization. According to Tyler and Caine(1991), transformational leaders provide the opportunity to their subordinates to voice their opinion in the decision making matters which are considered a fair practice from the subordinate's point of view. It has been suggested that the leaders who do not give much attention to the workplace fairness, reject the authority of the leaders (Rokhman \& Hassan, 2012). It has also been found out that organizational justice theory framework provides a basis for the understanding of individual's work attitude, job performance (Coquitt, 2001; Cropazano, Bowen and Gilliland, 2007). Thus it can be inferred that transformational leaders are considered as charismatic leaders who take care of the needs and wellbeing of their employees through the perception of fairness. A leader who thus follows fairness in the workplace is believed to have an open mind and responsive attitude. Thus for the proper functioning of an organization a transparent performance reward relationship has to be in place. Therefore, organizational justice places an important role in inducing work related positive emotions. Thus,

Proposition 3: Transformational leadership is positively and significantly related to the perception of organizational justice

\subsection{Organizational Learning and Psychological Empowerment}

Every individual is born with the ability to learn. Learning leads to new insights and concepts. It is a social phenomenon. According to Argyris and Schon (1978), detecting one's own mistakes and learning from these mistakes leads to the development of new ideas. Organizational learning is an important resource for a firm seeking to survive in today's competitive market (Barney, 1991). According to Auh and Mengue (2005), organizational learning is the ability of an organization to create, disseminate and thus act upon the generated knowledge. Empowerment on the other hand is an important concept as it acts as a potential motivational construct which is benefit to both the individual as well as the organization (Han \& et al, 2009). According to Thomas and Velthouse (1990), organizational environment plays a very important role on the empowerment of the employees. Empowerment increases the self-efficacy of the employees (Conger and Kanungo, 1990). Empowerment also leads to becoming more adaptive (Scott \& Bruce, 1994). The more the employees perceive an organization to provide them with learning opportunities, the more they will be psychologically attached to the organization (Joo \& Shim, 2010). The more the learning opportunities, the more highly empowered they shall feel and as a result they would be more committed to the organization (Linden, Wayne, Sparrowe, 2000). The more these positive work attitudes are promoted in the organization, the more the sense of ownership and psychological empowerment of the employees would be strengthened. Thus, 
Proposition 4: Psychological Empowerment of the employees will vary significantly with the varying levels of organizational learning within the organization.

\subsection{Organizational Justice and Psychological Empowerment}

Spreitzer (1995) defined empowerment as the internal job motivation manifested in the four dimensions of efficacy, impact, meaningfulness and competence. According to Sheykh \& Zivaryar (2006), the more the members of the firm accept the values of the firms, the more successful is the organization. ( $S$ Javad et al, 2009) opines that the preservation and development of fair practices and behaviour in manager's result in a perception of justice amongst the employees. According to Chenevert (2007), the integration of the variables of psychological empowerment and organizational justice helps in creating organizational commitment. In his research it is argued that if the employees feel that the processes in the organization are just and fair, then more will be the participation from the employees which shall result in increased organizational commitment. According to a research by (Alvandi et al, 2014) the unjust practices in the distribution of organizational achievements result in the lowering of the moral of the employees and their capabilities. The more the increased feeling of fairness, the more will be the increased employee participation (Greenberg, 1986). When the employees perceive that the rewards in organization are distributed according to merit and performance then their motivation is increased as stated by Vrooms theory of motivation. This also enhances the empowerment of employees. Thus the justice literature suggests that there is a link between perceptions of justice and the empowerment of the employees. Thus it can be proposed that organizational justice is one of the important ways of enhancing the psychological empowerment of the employees. The existence of a feeling of justice among the employees will lead to the motivation, education of the human resources and more efficacy in the working environment. Thus,

Proposition 5: Psychological Empowerment of the employees will vary significantly with the varying levels of organizational justice

\subsection{Organizational Learning mediates Transformational Leadership and Psychological Empowerment}

In the leadership literature it is proposed that in order to become a learning organization, leaders need to play the key role. They act as a guide and mentor to the followers and thus challenge the status quo assumptions of the followers (Altman and Iles, 1998; Appelbaum and Goransson, 1997; Argyris, 1973, 1977, 1993; Bartunek, 1984; Bennis and Nanus, 1985; Fiol, 1994; French and Bazalgette, 1996; Garvin, 1993; McGill and Slocum, 1993; McGill et al., 1992; Naot et al., 2004; Nonaka, 1988, 1991 1994; Nystrom and Starbuck, 1984; Smircich and Stubbart, 1985; Vera and Crossan, 2004; Williams, 2001 ). This can be interpreted in a way that the intellectual stimulation of the transformational leadership has the most important role to play. These leaders' challenges the follower's age old assumptions and help them in tackling old problems in a novel fashion and thus inspire the followers to think about the conventional methods critically and share the new ideas. Leaders need to create the necessary psychological and cultural conditions to promote organizational learning (Popper and Lipshitz, 2000). According to the researchers (Ellinger and Bostram, 1999; Goh, 1998; Hitt, 1995; Mills and Friessen, 1992), facilitative leaders serve as coaches and mentors and thus bring about the motivation in their followers. This can be interpreted in a way that transformational leaders promote in their employees the concept of out of the box thinking. This results in the employees being more creative and innovative. The employees thus consider themselves a valuable part of the organization. This results in positive attitude in the employees. They find meaning in the work they do and hence their psychological empowerment also increases. Thus,

Proposition 6: Organizational Learning mediates the relationship between transformational leadership and psychological empowerment of the employees such that transformational leadership will have stronger positive relationship with the psychological empowerment of the employees.

\subsection{Organizational Justice mediates Transformational Leadership and Psychological Empowerment}

Transformational leaders encourages their followers to work beyond their self-interests for the effective working of the organization (Bass and Avolio, 1994). These leaders always consider their employees needs first and think about their welfare. Such leaders always support their employees in putting forward their opinions, which is considered a fair practice from the employees' point of view (Tyler \& Caine, 1991). This can be interpreted in the manner that the transformational leaders treat their employees fairly well which elicits positive response from the employees by showing more commitment from their side towards their leaders as well as the organization in whole. This just and fair behaviour from the leader's side will also result in the nurturing of talents. Research shows that transformational leadership emphasize organisational justice in the organizations. Another important objective of any organization is to have empowered employees. To have empowered employees both leaders and just practices in the organization are very important. According to Greenberg, 1990 , organizational justice is the description and explanation of fair practices in the workplace. Justice in the organization results in the consistency of its employees, deficient of which may lead to the separation and faction among them (Folger \& Cropanzano, 1998). In a study by Cubert and Mcdonough (1980), empowerment is understood as the key to building trust and interactions in an organization. It can be said thus that leaders who create a positive working environment where the employees can trust their leaders and consider them to be fair , then such workforce becomes more empowered. Those employees are empowered who feel that their supervisors and managers understand their working conditions and 
commitment. Such a thing is possible as a result of organizational justice perceived by the employees (Bonab et al, 2014). Thus,

Proposition 7: Organizational Justice mediates the relationship between transformational leadership and psychological empowerment of the employees such that transformational leadership will have stronger positive relationship with the psychological empowerment of the employees.

\subsection{Transformational leadership and Psychological Empowerment}

Transformational leadership promotes behavioural changes in the employees to enable them to perform better (Bass, 1985; Bolino \& Turnley, 2003; Bowler, 2006). Psychological empowerment facilitates the employees with feelings of competence, meaning, resilience and responsibility for their work (Spreitzer, 1995; Kanter, 1979, 1983). According to a research by Thomas and Velthouse (1990), organizational environment plays a very important role in influencing the empowerment of employees. A research by Prabhakar (2005) claimed that truly great leaders instil confidence in its employees so that they perform more than expectations. This can be interpreted in a way that transformational leadership leads to the employees intrinsically motivated so that the employees may feel psychologically empowered. Transformational leaders motivate their employees to solve difficult tasks and thus achieve higher levels of capabilities (Ozaralli, 2003). Transformational leaders modify their ways of working by empowering their employees (Bowler, 2006). This enhances the morale of the employees as well as brings about moral, process and attitudinal changes in the organization as a whole. Thus it can be proposed that transformational leaders tend to act as a mentor, as a guide for their employees and thus help in uplifting their morale. As a result the employees 'confidence is boosted up and hence they are psychologically empowered. Thus,

Proposition 8: Transformational leadership is positively and significantly related to the Psychological Empowerment of the employees

\subsection{Psychological Empowerment and Organizational Identification of Employees}

In the literature, empowerment is of two types (Kanter, 1997) one is structural empowerment and the other one is the psychological empowerment. Structural empowerment is about power delegation whereas the psychological empowerment is the intrinsic motivational approach of empowerment (Menon, 2001). Studies have already revealed that the feelings of empowerment is found to enhance the employees "commitment and loyalty towards the organization (Kirkman and Rosen, 1999). It is also suggested in the literature that the employees who possess greater autonomy in their work are likely to feel more empowered (Sprietzer, 1995). This feeling of enhanced empowerment psychologically results in an increased feeling of pride to be associated with the organization; and thus results in an increased sense of identification with the organization (Koberg et al, 1999). Thus it is proposed that psychological empowerment is an important mechanism by which employees identify with their organization. Employees thus feel more emotionally attached to and involved in the organization as such a strong sense of being identified with the organization is thus increased. Thus,

Proposition 9: Psychological empowerment of employees leads to employees' Identification with the organization

\subsection{Psychological Empowerment mediates Transformational Leadership and Organizational Identification}

As mentioned earlier, the mechanism through which transformational leadership impacts organizational identification of employees has not yet been fully researched. It is thus proposed here that psychological empowerment of the employees do play an important role in this mechanism of influencing identification of the employees. Followers tend to identify with those leaders who envisions a desirable future, shows them the path by which to reach those goals, and thus instil in them a sense of determination and confidence (Balaji \& Krishnan, 2014). Transformational leaders give personal attention to each of its employees thus having a better relationship with them. Yukl (2010), hypothesized that if leaders empower their employees in achieving their objectives, a sense of commitment is fostered in them. There are empirical studies (Avolio , Zhu , Koh \& Bhatia , 2004 ; Fuller, Morrision , Jones , Bridger \& Brown , 1999 ; Kark et al. , 2003) that have shown the positive association between the constructs of transformational leadership and psychological empowerment of the employees. These studies have claimed that transformational leadership help in increasing social identification of the employees with the group or organization if the employees are empowered. Thus it can be said that transformational leaders are the visionary leaders who communicate their vision to their employees and thus make them believe in it. This increases in them a sense of importance of the work and also helps them in achieving a meaningful future. Thus a sense of ownership increases which results in the achievement of the employees 'psychological empowerment as well as identification with the organization. Thus,

Proposition 10: Psychological Empowerment mediates the relationship between transformational leadership and organizational identification of the employees

\section{SCOPE OF THE MODEL}

It is important to acknowledge that the relationship between transformational leadership and organizational identification of employees can be affected by other potential mediating factors such as culture, trust, communication, satisfaction etc.. Even if the proposed model is not assessing these concepts however indirectly transformational leadership is affected by these variables, have been addressed in the study. The process variables such as trust, communication, and satisfaction can be considered as follower's attitude towards the leaders that can establish positive relationship amongst the variables. 
According to a study by Podsakoff et al (1999), the followers 'willingness to trust the leaders will result in the follower's attitude towards the implication of transformational leadership. Thus the variables discussed above are important, and have been addressed indirectly in the current model which focusses in establishing the relationship between transformational leadership and organizational identification of the employees. Although the variables proposed in the model are not exhaustive, however it does attempt to explore the relationship between the constructs of transformational leadership and organizational identification of the employees.

\section{DISCUSSION AND CONCLUSION}

\subsection{Implication of the Model}

In this article a proactive approach is taken to integrate the concepts of the various constructs in establishing the relationship between transformational leadership and identification of the employees. First, the present model shall provide additional support to the managers to demonstrate a motivational mechanism for the transformational leadership theory, through which it may enable the followers to identify with their organizations. Second, the findings of the model may be helpful to provide guidance to the managers as to how transformational leadership may be utilized for the proper functioning of the organizations. Third, transformational leadership is an increasingly essential tool in the kit of managers looking to enhance employee empowerment and thus help in reducing the turnover in the increasingly competitive market. By examining the model and its proposed relationships it is expected that it will enable researchers to shed new light on this issue.

\subsection{Limitations of the Model}

Although this research makes several important contributions, however the proposed model has certain limitations that should be noted. Firstly, the proposed relationship in the model has not been tested and hence a concrete empirical evidence is thus not provided to confirm the relationships between the various mediating variables in establishing the relationship between transformational leadership and organizational identification of the employees. Second, it is arguable that other potential variables can be taken into consideration such as culture, trust, communication etc., however these variables are not used exclusivelyin this present model. Hence it is suggested that some of the variables can be included in the model for future investigations.

\subsection{Conclusion}

This article provides insights into the role of transformational leadership in determining the organizational identification of employees. This model is developed theorising the mediating effects of organizational learning, organizational justice and psychological empowerment in determining the relationship between transformational leadership and organizational identification of employees. The model suggests that the constructs of organizational learning, organizational justice, and psychological empowerment are important underlying mechanisms illuminating the effectiveness of transformational leadership for organizational identification of employees. This model shall provide additional support for transformational leadership theory by demonstrating a motivational mechanism through which employees identify with their organizations. It is envisaged that the proposed model will stimulate more research attention to exploring the theoretical and practical implications of transformational leadership for employee identification in organisations.

\section{REFERENCES}

[1] Aragón-Correa, J. A., V. J. García-Morales and E. Cordón-Pozo. (2005). Leadership and organizational learning's role on innovation and performance: lessons from Spain.Industrial Marketing Management, 36, 349-359.

[2] Argyris, C., \& Schon, D. (1978). Organizational Learning : A theory of action perspective. Reading MA: AddisonWesley.

[3] Ashforth, B.E. (1989). The experience of powerlessness in organisation. Organizational Behaviour and Human Decision Processes, 43, 207-242.

[4] Ashforth, B.E., \& Mael, F. (1989). Social Identity theory and the organization. Academy of management Review, 14(1), 20-39.

[5] Auh, S. \& Mengue, B. (2005). Balancing exploration and exploitation: the moderating role of competitive intensity. Journal of Business Research, 58, 1652-1661.

[6] Avolio BJ, Zhu W, Koh W and Puja B (2004). Transformational leadership and organizational commitment: Mediating role of psychological empowerment and moderating role of structural distance. Journal of Organizational Behavior, 25, 951-968.

[7] B Joo, J Shim (2010), Human Resource Development International, 13(4), 425-441.

[8] Balaji, M. \& Krishnan, R. (2014). Impact of transformational leadership on Empowerment: Mediating Role of Social Identity. International Journal on Leadership, 2(1), 34-42.

[9] Barling, J., Christie, A. M., \& Turner, N. (2008). Pseudo-transformational leadership: Towards the development and test of a model. Journal of Business Ethics, 81, 851-861. 


\section{ISSN 2278-5612}

[10] Barney, J.B. (1991). Organization resources and sustained competitive advantage. Journal of Management, 1, 99120.

[11] Bass, B M. (1985). Leadership and Performance beyond Expectations, Free Press, New York.

[12] Bass, B.M. \& Steidlmeier, P. (1999). Ethics, character and authentic transformational leadership behaviour. Leadership Quarterly, 10(2), 181-187.

[13] Bhat, Rangnekar and Barua (2013). Impact of transformational leadership style on Organizational Learning. Elite Journal of Education and Review, 1(4), 24-31.

[14] Bolino, M. C. \& Turnley, W. H. (2003). "Going the extra mile: Cultivating and managing employee citizenship behavior". Academy of Management Executive, 17(4), 60-71.

[15] Brief, A.P. and Nord, W.R. (1990). Meanings of Occupational Work, Lexington Books, Lexington, MA.

[16] Brown, A.D. (1994), Transformational Leadership in tackling technical change. Journal of General Management, 19(4), 1-12.

[17] Brown, S.L., and Eisenhardt, K.M. (1997), The art of continuous change: Linking complexity theory and time-paced evolution in relentlessly shifting organizations. Administrative Science Quarterly, 42(1), 1-34.

[18] Burns, J. M. (1978). Leadership. New York: Harper \& Row.

[19] Chandna, P. \& Krishnan, R (2009).Organizational Commitment of Information Technology Professionals: Role Of Transformational Leadership And Work-Related Beliefs. Tecnia Journal of Management Studies, 4(1), 1-13.

[20] Colquitt., J.A.(2001). On the dimensionality of organizational justice: A construct validation of a measure. Journal of Applied Psychology, 86(3), 386-400.

[21] Conger, J.A., \& Kanungo, R.N. (1988). The Empowerment Process Integrating theory and practice. Academy of Management Review, 13(3), 471-482.

[22] Crawford, C.B. (2005). Effects of transformational leadership and organizational position on knowledge management. Journal of Knowledge Management, 9(6), 6-16.

[23] Cropanzano, R., Bowen, D.E., \& Gulliland, S.W.(2007).The management of organizational justice. Academy of Management Perspectives, 21, 34-48.

[24] Deci, E.L. and Ryan, R.M. (1985). Intrinsic Motivation and Self Determination in Human Behavior, Plenum, New York.

[25] Dodgson, M. (1993), “Organizational learning: a review of some literatures”, Organization Studies, vol. 14 no. 3 , pp. 375-394.

[26] Figueiredo, P. (2003). Learning, capability accumulation and firms differences: evidence from latecomer steel. Industrial and Corporate Change, 12(3), 607-643.

[27] Fuller, J.B., Patterson, C.E.P., Hester, K., \& Stringer, D.Y. (1996). A quantitative review of research on charismatic leadership. Psychological Reports , 78, 271-287

[28] Ganapathy, S., \& Kumar, V. (2000). A flexible learning approach towards enduring organizational competence. In M.K. Sushil\& O. Sharma (Eds.), New Business Paradigm: Global, Vertical and Flexible, 1059-1068.

[29] Garcia-Morales, V. J., Jiménez-Barrio Nuevo, M. M., \& Gutiérrez-Gutiérrez, L. (2012).Transformational leadership influence on organizational performance through organizational learning and innovation. Journal of Business Research, 65 (7), 1040-1050.

[30] Gist, M and Mitchell, T.N. (1992). Self-Efficacy: A theoretical analysis of its determinations and malleability. Academy of Management Review, 17, 183-211.

[31] Greenberg, J. (1987). A taxonomy of organizational justice theories. Academy of Management Review, 12(1), 9-22.

[32] Greenberg, J. (1990), Organizational Justice: Yesterday, today and tomorrow. Journal of Management, 16(2), 319342.

[33] Han, Sang-Sook., Moon, Sook, Ja. \&Yun, EunKyoung, (2009). Empowerment, job satisfaction, and organization commitment : comparison of permanent and temporary nurses in Korea. Applied Nursing Research, 22(4), 15-20.

[34] Hater, J.J. \& Bass, B.M. (1988). Superiors' evaluation and subordinates perceptions of transformational and transactional leadership. Journal of Applied Psychology, 73(4), 695-702.

[35] Homans, G. C. (1950). The human group. New York: Harcourt, Brace.

[36] Joo, B., and Shim, J.( 2010). Psychological empowerment and organizational commitment: the moderating effect of organizational learning culture, Human Resource Development International, 13(4), 425-441.

[37] Judge TA and Piccolo RF (2004) Transformational and transactional leadership: A meta-analytic test of their relative validity. Journal of Applied Psychology, 89(5), 755-768. 
[38] Hugo, Z., Vlado D., \& Miha, S. (2009). Transactional and transformational leadership impacts on organizational learning. Journal for East European Management Studies, 2, 144-165.

[39] Kanungo, R.N., and Misra, S. (2004), Motivation, leadership, and human performance. In J. Pandey (Ed.), Psychology in India revisited: Developments in the Discipline (Vol. 3) (pp. 309-341). New Delhi: Sage Publications.

[40] Kark, R., Shamir, B., \& Chen, G. (2003). The two faces of transformational leadership: Empowerment and dependency. Journal of Applied Psychology, 88(2), 246-255.

[41]

[42] Kirkman, B. L., \& Rosen, B. (1999). Beyond self-management: Antecedents and consequences of team empowerment. Academy of Management Journal, 42, 58-74.

[43] Klenke, K. (1994), Information Technologies as drivers of emergent organizational forms: A leadership perspective. In R. Baskerville, S. Smithson, O Ngwenyama and J.I.DeGross. Transforming organizations with information technology. North Holland, Elsevier Science B.V.

[44] Koberg, C. S., Boss, R. W., Senjem, J. C., \& Goodman, E. A. (1999). Antecedents and outcomes of empowerment. Group \& Organization Management, 24(1), 71-90.

[45] Kurland H, et al, Journal of Educational Administration,2010, 48(1), 7-3

[46] Lowe, K. B., Kroeck, G. K., \& Sivasubramaniam, N. (1996). Effectiveness correlates of transformational and transactional leadership: A meta-analytic review of the MLQ literature. The Leadership Quarterly, 7, 385-425.

[47] Menon, S.R.(2001). Employee empowerment: An integrative psychological approach. Applied Psychology: An international review, 50(1),153-180.

[48] Newberry DB, PhD thesis, Capella University, 2008

[49] Piccolo, RF, \& Colquitt, JA 2006, Transformational leadership and job behaviors: the mediating role of core job characteristics. Academy of Management Journal, 49(2), 327-340.

[50] Pillai, R, Schriesheim, C, \& Williams, E. 1999, Fairness perceptions and trust as mediators for transformational and transactional leadership: a two-study sample. Journal of Management, 25(6), 897-933.

[51] Podsakoff, P. M., MacKenzie, S. B., \&Bommer, W. H. (1996).Transformational leader behaviors and substitutes for leadership as determinants of employee satisfaction, commitment, trust and organizational citizenship behaviors. Journal of Management, 22, 259-298.

[52] Linden, R.C., Wayne, S.J., \& Sparrowe, R.T.(2000). Journal of Applied Psychology, 85(3), 407-416.

[53] Rokhman, W. \& Hassan, A. (2012). Transformational Leadership and Work Outcomes: Organizational Justice as Mediator. World Review of Business Research, 2(4), 164-171.

[54] Scott, S.G. , \& Bruce, R.A.(1994). Determinants of innovative behaviour: a path model of individual innovation in the work place. Academy of Management Journal, 37, 580-607.

[55] Shamir, B., House, R. J., \& Arthur, M.B. (1993). The motivational effects of charismatic leadership: A self-concept theory. Organizational Science, 4(4), 577-594.

[56] Sheikh, M., Bagherzadeh, F., Zivaryar, F., Gholamalizadeh, R., Esmaeili, H., Fazel, J. (2005). "Evaluation of the organizational commitment of employees to the Department of Physical Education and Health Education", Journal Harakat, Vol.26, PP:5-22.

[57] Singh K, Organisation change and development, New Delhi: excel books publisher, 2005 .

[58] Spreitzer, G.M. (1995). Psychological Empowerment in the workplace: Dimensions, measurement and validation. Academy of Management Journal, 38(5),1442-1465.

[59] Thomas, K.W. and Velthouse, B.A. (1990). Cognitive elements of empowerment: An interpretive model of intrinsic task motivation. Academy of Management Review, 15, 666-681.

[60] Tyler, T. R. and A. Caine (1981). The influence of outcomes and procedures on satisfaction with formal leaders. Journal of Personality and Social Psychology 41(4): 642-655.

[61] Wahibur, R. \& Hassan, A.(2012). Transformational Leadership and Work Outcomes: Organizational Justice as mediator.

[62] Wang, G., \& Lee, P. (2009). Psychological empowerment and job satisfaction: An analysis of interactive effects. Group \& Organization Management, 34(3), 271-296.

[63] Yukl, G. (2010). Leadership in organizations (7th edition). Upper Saddle River, NJ: Prentice Hall.

[64] Yukl, G. \& Van-Fleet, D.D., (1992). Theory and research on leadership in organizations. New York: Free Press.

[65] Zhu ,W. ,Sosik , J. , Riggio , R. , Yang, B.(2012) ,Leadership and Organizational Identification , 186-212. 